\title{
DesinFix TM 135 in fermentation process for bioethanol production
}

\author{
Dorothee Barth ${ }^{4}$, Ana Raquel de Souza Monteiro ${ }^{2}$, Marcelo Moreira da Costa ${ }^{1}$, \\ Ilkka Virkajärvi $^{3}$, Vera Sacon ${ }^{2}$, Annika Wilhelmsom $^{4}$ \\ ${ }^{1}$ Kemira Chemicals Brazil, São Paulo, SP, Brazil. \\ ${ }^{2}$ VTT Brasil, São Paulo, SP, Brazil. \\ ${ }^{3}$ Kemira Oyj, Helsinki, Finland. \\ ${ }^{4}$ VTT Technical Research Centre of Finland, Espoo, Finland.
}

Submitted: October 19, 2012; Approved: September 9, 2013.

\begin{abstract}
Brazil has the world's largest ethanol production from sugarcane, but bacterial contamination decreases the ethanol yields. It was shown that the biocide DesinFix ${ }^{\mathrm{TM}} 135$ can reduce the contamination without decreasing the yeasts' viability or negatively affecting the ethanol production.
\end{abstract}

Key words: ethanol production, fermentation process, sugar cane feedstock, biocides, bioethanol.

The dominant bioethanol feedstock in tropical regions is sugarcane. Brazil has the world's largest bioethanol production from sugarcane crop raw material. It was reported that the bioethanol production is expected to be about 23.96 billion liters in 2012 (Conab, 2012). Alcoholic fermentation is a biological process in which yeast (Saccharomyces cerevisiae) converts sugars, e.g., glucose, fructose, and sucrose into cellular energy with ethanol and carbon dioxide as metabolic products. Producing ethanol provides the yeast with a way to store energy but also to avoid competition, since the presence of ethanol creates a toxic environment to some microorganisms (Rosa et al., 2006). However, several other microorganisms are able to share the same environment with the $S$. cerevisiae and consume sugar for their own metabolism. Therefore, the contamination in fermentation tanks by bacteria is one of the main problems in ethanol production mills.

Lactobacillus spp. bacteria are known as the most predominant contaminants in ethanol fermentation processes using tapioca and corn as feedstock (Chang et al., 1995; Skinner and Leathers, 2004). According to a reviewed list (Oliva-Neto and Yokoya, 1998; Alcarde et al., 2003; Meneghin, 2008; Saithong et al., 2009) the five most common organisms present in the ethanol fermentation process with sugarcane juice and/or with molasses are: a) Lactobacillus fermentum; b) Lactobacillus paracasei; c)
Lactobacillus planetarium; d) Leuconostoc mesenteroides; e) Bacillus subtillis. These bacteria can cause inhibition of S. cerevisiae growth and limit the ethanol production. This is due to two major facts: [1] the production of acetic and lactic acids and [2] the competition for nutrients (Beckner et al., 2011; Muthaiyan et al., 2011).

Usually, fermentation mills combat the contamination problem by adding antibiotics, sulfuric acid, oxidants or other microbiocides in the fermentation tanks. The most common method for contamination control is a sulfuric acid treatment of the yeast cream. At the beginning of the regular fermentation process, sulfuric acid lowers the $\mathrm{pH}$ of the yeast cream to 2 ; then the yeast cells are incubated for 2 hours at that $\mathrm{pH}$ before returning to the fermenter. This common treatment is not completely satisfying, since it may have a negative influence on the yeast metabolism via low $\mathrm{pH}$. The yeast metabolism is optimal for growth in an environment with a $\mathrm{pH}$ from 4 to 6 . At lower external $\mathrm{pH}$, the intracellular $\mathrm{pH}$ of the yeast cell may be affected, whereby enzyme functions may be impaired and as consequence, all yeast metabolism can be damaged. This has major influence on the fermentation time and ethanol yield (Narendranath and Power, 2005).

Kemira Oyj developed a new biocide for the control of bacteria in ethanol fermentation processes: DesinFix ${ }^{\mathrm{TM}}$ 135, a performic acid (PFA) solution produced on site. DesinFix $^{\mathrm{TM}} 135$ is a strong oxidizing, non-antibiotic agent 
which kills microbes by destroying cell membrane functions. DesinFix ${ }^{\mathrm{TM}} 135$ will decompose during the fermentation process into $\mathrm{CO}$ and $\mathrm{H}_{2} \mathrm{O}$, leaving no residues.

In order to evaluate the best conditions for the application of DesinFix ${ }^{\mathrm{TM}} 135$, experiments were performed at laboratory and pilot plant at sugar mill. The main objective of this work was to test the efficiency and selectivity of DesinFix ${ }^{\mathrm{TM}} 135$ in controlling the bacterial contamination while ensuring yeast viability and ethanol production.

The laboratory trials showed the efficiency of the product in a sucrose solution contaminated with a bacterial mix (Table 1). Sucrose solution was used as a model medium instead of molasses. After only 10 min of contact time with $10 \mathrm{mg} \mathrm{L}^{-1} \mathrm{PFA}$, the microbial count of the sucrose solution decreased from $10^{7}$ to below $10^{3}$. The effect of PFA on the bacterial count was dose-dependent. This result shows that DesinFix ${ }^{\mathrm{TM}} 135$ has a fast killing effect. The bacterial mix was composed of Lactobacillus fermentum, Lactobacillus paracasei, Lactobacillus planetarium, Leuconostoc mesenteroides. These bacteria were provided by the VTT culture Collection in Finland.

Table 2 shows measurement data from pilot plant trials performed in a sugar cane mill in Brazil. These experiments were performed in different conditions on each day, each day representing one batch of fermentation. On days 1 and 5, $60 \mathrm{mg}$ of PFA per liter was added to the yeast cream; on day 2, $20 \mathrm{mg}$ of PFA per liter was added to the yeast cream and $20 \mathrm{mg}$ of PFA per liter was added to the must tank; on days 4, 6 and 7, $20 \mathrm{mgL}^{-1}$ was added to the yeast cream and $5 \mathrm{mg} \mathrm{PFAL}^{-1} \mathrm{~h}^{-1}$ applied to the must tank divided in 4 steps. Day 3 is the reference day without PFA addition. On the reference day only the mill's standard sulfuric acid treatment was carried out: sulfuric acid was added to the yeast cream until it reached a $\mathrm{pH}$ between 2.0 and 2.25. The wine was evaluated at the end of each fermentation. The level of bacterial contamination after PFA application did not differ significantly from that of the reference day.

Table 1 - Results from disinfection experiment with PFA in contaminated sucrose solution ${ }^{\S}$.

\begin{tabular}{lcc}
\hline $\begin{array}{l}\text { DesinFix } \\
\left(\mathrm{mg} \mathrm{PFAL}^{-1}\right)\end{array}$ & $\begin{array}{c}\mathrm{THAB} \#^{\S \S}\left(\mathrm{cfu} \mathrm{mL}^{-1} \text { after }\right. \\
10 \mathrm{~min} \text { from PFA addi- } \\
\left.\text { tion }^{\S \S}\right)\end{array}$ & $\begin{array}{c}\mathrm{THAB} \#^{\S \S}\left(\mathrm{cfu} \mathrm{mL}^{-1} \text { after }\right. \\
60 \mathrm{~min} \text { from PFA addi- } \\
\text { tion })\end{array}$ \\
\hline 0 (control) & $6.5 \times 10^{7}$ & $7.6 \times 10^{7}$ \\
5 & $3.9 \times 10^{4}$ & $2.5 \times 10^{4}$ \\
10 & $<1.0 \times 10^{3}$ & $<1.0 \times 10^{3}$ \\
$>20$ & $<1.0 \times 10^{1}$ & $<1.0 \times 10^{1}$ \\
\hline
\end{tabular}

${ }^{\S}$ composition of solution: $200 \mathrm{gL}^{-1}$ of sucrose in distilled water with the addition of $0.5 \mathrm{gL}^{-1}$ urea $\left(\left(\mathrm{NH}_{2}\right)_{2} \mathrm{CO}\right)$ and $0.01 \mathrm{mgL}^{-1}$ zinc chloride $\left(\mathrm{ZnCl}_{2}\right)$.

${ }^{\S}$ THAB $\#=$ Total Heterotrophic Aerobic Bacteria, Lactobacillus fermentum, Lactobacillus paracasei, Lactobacillus planetarium, Leuconostoc mesenteroides.

${ }^{\S \S \S} \mathrm{CFU}=$ Colony Forming Units; determined by plating samples on MRS-agar (Difco laboratories), incubating at $30{ }^{\circ} \mathrm{C}$ for 3 days and counting the number of colonies formed.

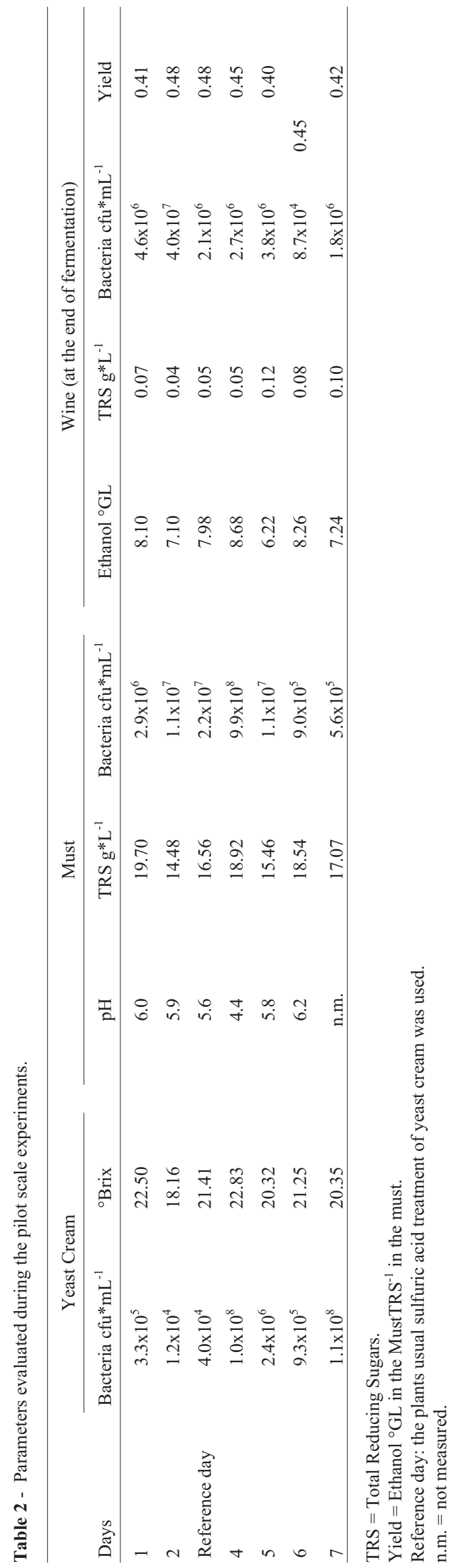


These results show that Desinfix ${ }^{\mathrm{TM}} 135$ is as effective in reducing bacterial contamination as sulfuric acid and can therefore be used as decontamination agent. Another point to be noted is that the $\mathrm{pH}$ is not negatively influenced by the use of Desinfix ${ }^{\mathrm{TM}} 135$. A stable $\mathrm{pH}$ keeps the yeast metabolism functioning properly. The sulfuric acid treatment lowers the $\mathrm{pH}$ of the yeast cream to between 2.0 and 2.25, which is too low for the yeast cell to maintain its metabolic functions. When the must is fed to the yeast tank, the $\mathrm{pH}$ increases to approximately 5.0 and the yeast cell functions are recovered. Using Desinfix ${ }^{\mathrm{TM}} 135$, this stress caused to the yeast cells by the sulfuric acid is avoided, since adding Desinfix $^{\mathrm{TM}} 135$ to treat the yeast cream during the tests from days 5 to 8 showed that the $\mathrm{pH}$ was kept between 4.6 and 5.3.

Several laboratory tests were performed in different kinds of media (containing sugar cane juice, molasses and water in different ratios) and the variability of the results seems to indicate that the efficiency of DesinFix ${ }^{\mathrm{TM}} 135$ to control microbial contamination in sugar cane ethanol mills depends on the medium composition data not shown). Some oxidizing power of performic acid seems to be lost when the medium is very rich in color and organic matter (e.g. when the medium contained only molasses diluted with water, but no sugar cane juice). Therefore, the application procedure in industrial scale will depend on the practices of the particular mill. However, the results show that in suitable conditions, DesinFix ${ }^{\mathrm{TM}} 135$ can reduce microbial contamination in significant amounts (at least 2 logs decrease with the amounts tested), maintain a stable $\mathrm{pH}$, be at least as efficient as sulfuric acid but without the potential negative effects on yeast metabolism and fermentation performance associated with sulfuric acid treatment. The cost of DesinFix ${ }^{\mathrm{TM}} 135$ treament can be higher than sulfuric acid treatment alone. However, the effectiveness of Desinfix ${ }^{\mathrm{Tm}}$ 135 makes additional use of antibiotics unnecessary and may even give slight increases in ethanol yields in the process, thus making the use of Desinfix ${ }^{\mathrm{TM}} 135$ a cheaper op- tion. The biocide Desinfix ${ }^{\mathrm{TM}} 135$ can therefore be considered a viable non-antibiotic alternative to sulfuric acid treatment during industrial sugar cane/molasses fermentation for ethanol production.

\section{References}

Alcarde AR, Walder JMM, Horii J (2003) Fermentation of irradiated sugarcane must. Sci agric 60:677-681.

Beckner M, Ivey ML, Phister TT (2011) Microbial contamination of fuel ethanol fermentations. Lett App Microbiol 53:387-394.

Chang, In-Seop, Kim B, Shin P, Lee W (1995) Bacterial contamination and its effects on ethanol fermentation. J Microbiol Biotechn 5:309-314.

CONAB (2012) Acompanhamento de safra brasileira: cana-deaçúcar, primeiro levantamento, abril/2012. Conab Brasília.

Meneghin SP, Reis FC, Almeida PG, Ceccato-Antonini SR (2008) Chlorine dioxide against bacteria and yeasts from the alcoholic fermentation. Braz J Microbiol 39:337-343.

Muthaiyan A, Limayem A, Ricke SC (2011) Antimicrobial strategies for limiting bacterial contaminants in fuel bioethanol fermentations. Prog Energ Combust 37:351-370.

Narendranath NV, Power R (2005) Relationship between $\mathrm{pH}$ and Medium Dissolved Solids in terms of growth and metabolism of lactobacilli and Saccharomyces cerevisiae during ethanol production. Appl Environ Microb 71:2239-2243.

Oliva-Neto P, Yokoya F (1998) Effect of 3,4,3'-Trichlorocarbanilide on growth of lactic acid bacteria contaminants in alcoholic fermentation. Bioresource Technol 63:17-21.

Rosa C, Gábor P, Rodrigues FJS, Ludovico P, Leão C (2006) Biodiversity and ecophysiology of yeasts. Sugar metabolism in yeasts: an overview of aerobic and anaerobic glucose catabolism. Springer 6:101-121.

Saithong P, Nakamura T, Shima J (2009) Prevention of bacterial contamination using acetate-tolerant Schizosaccharomyces pombe during bioethanol production from molasses. $\mathrm{J}$ Biosci Bioeng 3:261-319.

Skinner KA, Leathers TD (2004) Bacterial contamination of fuel ethanol production. J Ind Microbiol Biot 31:401-408.

All the content of the journal, except where otherwise noted, is licensed under a Creative Commons License CC BY-NC. 